\title{
Historia równości z happy endem
}

\author{
DOI 10.35757/CIV.2014.16.10
}

Tomasz Kizwalter: $W$ stronę równości, Wydawnictwo Universitas, Kraków 2014, ss. 198.

Pod koniec 2014 roku do rak czytelników trafiła publikacja Tomasza Kizwaltera $W$ stronę równości wydana przez krakowskie wydawnictwo Universitas. Autor jest profesorem w Instytucie Historycznym Uniwersytetu Warszawskiego. Od lat specjalizuje się $\mathrm{w}$ dziewiętnastowiecznej historii idei. W szczególności upodobał sobie temat, który określić można jako „zmagania Polaków z nowoczesnościa”. Tego właśnie dotyczyły jego najważniejsze prace $z$ lat dziewięćdziesiatych: "Nowatorstwo i rutyny". Społeczeństwo Królestwa Polskiego wobec procesów modernizacji1, a przede wszystkim O nowoczesności narodu. Przypadek polski², która to książka - po wywołaniu debaty wśród historyków i socjologów - w 2013 roku została wydana $\mathrm{w}$ języku niemieckim ${ }^{3}$.

Kizwalter jest też m.in. innymi autorem syntezy dziejów powszechnych $\mathrm{w}$ dziewiętnastym wieku ${ }^{4}$. $W$ stronę równości to kontynuacja badań nad tą problematyką: historia pojęć równości i nierówności w myśli Zachodu od Arystotelesa po wiek dwudziesty. Szczególnie miejsce zajmuje w tej analizie przypadek polski, któremu poświęcono osobna część pracy. Autor jest historykiem, który umiejętnie porusza się po obszarach filozofii i socjologii, więc książka powinna zainteresować przedstawicieli przynajmniej tych dwóch specjalności. Może ona posłużyć jako historyczna per-

1 T. Kizwalter: "Nowatorstwo i rutyny". Społeczeństwo Królestwa Polskiego wobec procesów modernizacji (1840-1863), Państwowe Wydawnictwo Naukowe, Warszawa 1991.

2 Idem: O nowoczesności narodu. Przypadek polski, Wydawnictwo Semper, Warszawa 1999.

3 Idem: Über die Modernität der Nation. Der Fall Polen, przekład B. Hartmann, Fibre, Osnabrück 2013.

4 Idem: Historia powszechna. Wiek XIX, Wydawnictwo Trio, Warszawa 2007. 
spektywa dla dwóch publicznych debat. Po pierwsze, wpisuje się w szeroki nurt rozważań nad nierównościami (zwłaszcza ekonomicznymi), ich rolą i pogłębieniem się po kryzysie z 2007 roku. Mam na myśli między innymi książki Stuarta White'a ${ }^{5}$, Tomáša Sedláčka ${ }^{6}$, Thomasa Piketty'ego ${ }^{7}$. Na polskim gruncie ów nurt przyjął postać dyskusji nad „równościowymi” dokonaniami III RP, w których brali udział między innymi Karol Modzelewski i Marcin $\mathrm{Król}^{8}$. Po drugie zaś, pojawiaja się w ostatnim czasie próby całościowego uchwycenia historii Polski (także Ludowej) i jej specyfiki - najgłośniejsze autorstwa Andrzeja Ledera ${ }^{9}$ i Jana Sowy ${ }^{10}$. Książki Kizwaltera w żaden sposób nie można określić mianem polemicznej. Odwołuje się tylko do pierwszej $z$ wyżej wymienionych pozycji. Kizwalter od autorów współczesnych woli generalnie klasyków myśli politycznej i społecznej, i to do nich najczęściej odnosi swoje uwagi.

Już samo naszkicowanie struktury książki nie jest proste. Składa się ona $z$ trzech części, które sa podzielone na rozdziały. Część pierwsza przedstawia historię pojęcia równości od czasów starożytnych do końca XIX wieku. Druga - to wykład dziejów Polski i jej doświadczeń $z$ nierównością. Jest ona tak bardzo oderwana od wcześniejszych rozważań, że właściwie można ją traktować jako oddzielna całość. W części trzeciej - najkrótszej i podsumowującej - autor stara się zarysować swoja generalną tezę.

Najogólniejsza definicja nierówności, według Autora, to przeświadczenie o istnieniu w społeczeństwie dwóch grup: predestynowanej do aktywności politycznej elity oraz naturalnie jej poddanej

\footnotetext{
5 S. White: Równość, przekład M. Wilk, Wydawnictwo Sic!, Warszawa 2008.

6 T. Sedláček: Ekonomia dobra i zła, przekład D. Bakalarz, StudioEMKA, Warszawa 2012.

7 T. Piketty: Kapitał $w$ XXI wieku, przekład A. Bilik, Wydawnictwo Krytyki Politycznej, Warszawa 2015.

8 M. Król: Byliśmy głupi, Wydawnictwo Czerwone i Czarne, Warszawa 2015; K. Modzelewski: Zajeździmy kobyłe historii. Wyznania poobijanego jeźdźca, Wydawnictwo Iskry, 2013, s. 375-427.

9 A. Leder: Prześniona rewolucja. Ćwiczenia z logiki historycznej, Wydawnictwo Krytyki Politycznej, Warszawa 2014.

10 J. Sowa: Fantomowe ciało króla. Peryferyjne zmagania z nowoczesna forma, Wydawnictwo Universitas, Kraków 2012; idem: Inna Rzeczpospolita jest możliwa. Widma przeszłości, wizje przyszłości, Grupa Wydawnicza Foksal, Warszawa 2015.
} 
„reszty”. Wszelkie inne nierówności - ekonomiczne, społeczne, tożsamościowe - uznawane sa przez niego za przejawy lub konsekwencje tej pierwotnej kategorii.

„Epokę nierówności”, w której traktowana jest ona jako naturalny element świata (nie tylko społecznego) wyznaczaja starożytność i średniowiecze. Uwzględniając specyfikę tych czasów, autor zastanawia się nad momentem, w którym to dominujące przez wieki przekonanie zaczynało być kwestionowane.

Nieprzypadkowo użyłem słowa „kwestionować”. Zdaniem warszawskiego historyka zmiana sposobu myślenia o równości nie dokonała się pod wpływem nacisku zewnętrznego, lecz w wyniku „odgórnej”, powolnej zmiany ideowej wśród elit. Kizwalter zgadza się z Leszkiem Kołakowskim, że dojrzała kulturę europejska znamionuje zdolność do samokrytycyzmu i umiejętność zakwestionowania utrwalonych poglądów i tradycji. Takie dojrzewanie zaczęło się w wieku XVIII. Jednym $z$ jego elementów był przełom w patrzeniu na społeczeństwo. Dowartościowaniu klas niższych towarzyszyło odkrycie przysługującej wszystkim bez wyjątku przyrodzonej godności. Elitaryzm zmieniał się w egalitaryzm. Nie była to zmiana szybka i bezbolesna - co autor źródłowo uzasadnia - ale miała charakter nieodwracalny.

W części pierwszej na szczególną uwagę zasługuje rozdział trzeci. Kizwalter przedstawia w nim różne sposoby opisu gwałtownych protestów ulicznych: w starożytnym Rzymie i rewolucyjnej Francji. Strach przed ludowymi rozruchami, przed demagogami i „wichrzycielami” jest stałym elementem politycznej wyobraźni. Najciekawsze, że to poczucie może mieć nawet władza, która deklaruje się jako „równościowa”. Szkoda, że autor nie odwołał się w tym miejscu do pracy Mariusza Mazura, przedstawiajacej propagandowy obraz protestów z czerwca 1976 roku, w której opisy ulicznych zamieszek i ich „prowodyrów” uderzająco przypominają te cytowane przez Kizwaltera ${ }^{11}$.

${ }_{11}^{11}$ M. Mazur: Propagandowy obraz świata. Polityczne kampanie prasowe $w$ PRL, 1956-1980. Model analityczno-koncepcyjny, Wydawnictwo Trio, Warszawa 2003. 
W drugiej części pracy autor stara się przyłożyć kategorie równości i nierówności do doświadczenia polskiego. Nie jest oryginalny, gdy stwierdza, że podstawowym antagonizmem występujacym w społecznych dziejach Polski był konflikt szlachecko-chłopski. Zgodnie $z$ Kizwalterowską definicją nierówności, jej rdzeniem było przekonanie warstw wyższych o nieomal genetycznym uprzywilejowaniu panów w stosunku do chłopów i ich naturalnej podległości. W ciekawy sposób autor pokazuje trwałość tej idei od końca XVIII wieku. W ten czy inny sposób podzielały ja nawet najbardziej radykalne grupy politycznej emigracji. Autor w przekonujacy sposób pokazuje, że, podobnie jak w XX wieku, łatwo powracały pańsko-chłopskie schematy stosunków.

Podkreśla jednocześnie, że pomimo istnienia autentycznego konfliktu, który czasem przyjmował gwałtowne formy (tu zwracam uwage na oryginalny opis rabacji galicyjskiej), Polska nigdy nie była arena krwawych walk klasowych. To ważne, bo tezę o głęboko zakorzenionej chłopskiej nienawiści do panów i wynikających $z$ niej różnych formach przemocy lansuje w Prześnionej rewolucji Andrzej Leder. Kizwalter w korespondencyjnej polemice podkreśla, że nie miało to miejsca ani pod zaborami, ani w II RP, ani za okupacji. Nawet kolektywizacja $z$ lat czterdziestych i pięćdziesiątych, która w propagandzie przedstawiana była jako rodzaj historycznej odpłaty, spotkała się $z$ ludowym oporem.

$Z$ analizy polskich (i nie tylko) zmagań $z$ równościa Kizwalter wyciaga wniosek, że modernizacja przeprowadzona na siłę nie niweluje negatywnych zjawisk społecznych, lecz jeszcze je wyostrza. Egalitaryzacja społeczna nie równa się autentycznej demokratyzacji. Mówiąc obrazowo: PRL-owskiego dyrektora $z$ awansu społeczno-politycznego dzieliło od szeregowego robotnika znacznie mniej niż „jaśnie pana” od parobka - zasada nierówności pozostawała jednak w mocy.

Zakończenie jest niezwykle optymistyczne. Rewolucyjnym zjawiskiem w powojennej Europe, zdaniem Kizwaltera, był trwajacy do końca lat sześćdziesiątych wzrost gospodarczy. Dzięki mądrej 
polityce redystrybucji udało się utrzymać społeczny ład. Dopiero całkowite zaspokojenie potrzeb materialnych stworzyło warunki do autentycznej egalitaryzacji i demokratyzacji. Nie oznaczało to jednak, że zniknęli „równościowi” krytycy Zachodu. Wręcz przeciwnie. Kizwalter swoją uwage skupia na tych $z$ lewicy.

„Teza, do której zamierzam przekonać czytelników - pisze autor w podsumowaniu - mówi, że zmierzamy w stronę równości”. Takie przekonanie wynika $z$ widzenia przemian społecznych $\mathrm{w}$ długiej historycznej perspektywie. Na przykładzie pojęcia „wykluczenia” jako opisu stanu nienormalności pokazuje, że żyjemy w czasach, w których równość jest czymś naturalnym. Wbrew dominującym dziś opiniom twierdzi, że wzrost gospodarczy sprzyja niwelowaniu nierówności, a nie ich pogłębieniu. Wspomniałem wcześniej, że $W$ stronę równości można potraktować jako głos w sporze o społeczne skutki transformacji ustrojowej w Polsce. Kizwalter zajmuje w nim stanowisko zdecydowanie optymistyczne: dopiero po 1989 roku widzi szansę na autentyczna demokratyzację Polski. Niestety, nie rozwija tego watku, zaznaczajacc tylko swoje zdanie. Warszawski historyk $z$ wyraźna sympatia patrzy na emancypacje polityczna i społeczną, a już $z$ mniejszą na nowoczesne formy walki o równość płci, orientacji seksualnych czy stylów życia.

Filozofowie moga się zżymać na metody, jakimi posługuje się autor, dyskutując $z$ klasycznymi i dwudziestowiecznymi teoriami. Wybrał formułę zapożyczona od Jerzego Jedlickiego: „nie zapuszcza się na głębokie wody teorii $z$ obawy utonięcia”"12. Analizy tekstów filozoficznych dokonuje w granicach swoich kompetencji: zaznacza zdanie odrębne, często posługuje się doświadczeniem historiografii, aby wykazać nadmierne uproszczenia i generalizacje. Nie jest to, rzecz jasna, wyczerpująca polemika, ale myślę, że zawsze warto spojrzeć na teorię oczyma krytycznego outsidera, a już w szczególności na swoich intelektualnych ulubieńców.

Kolejny problem to pewne przeładowanie treścia, które sygnalizowałem już przy omawianiu struktury książki. Tomaszowi Kizwal-

${ }^{12}$ T. Kizwalter: W stronę równości..., s. 183. 
terowi równość kojarzy się nieomal ze wszystkim: z praca, demokracja, modernizacja, przemianami mentalnymi i gospodarczymi, kontrola seksualności, z nacjonalizmem... Zazwyczaj słusznie! Niektóre watki podejmowane sa jednak trochę na siłę. Przykłady to zbyt skrupulatne odtworzenie przebiegu uwłaszczenia chłopów na ziemiach polskich, referowanie debat wokół naturalności narodu czy wokół nowoczesności Holokaustu. Powoduje to brak miejsca na refleksję, interpretację bądź zdefiniowanie podstawowych pojęć.

$Z$ pewnością nie będą usatysfakcjonowani ci, którzy w książce szukać będa prostych rozwiązań. Oto próbka odpowiedzi na pytanie, czy XIX wiek zbliżył, czy oddalił od siebie polskie ziemiaństwo i chłopów: „Można [...] zauważyć takie czynniki, których oddziaływanie zmniejszało ów dystans i takie, których wpływ miał odmienne następstwa".

$W$ stronę równości to mimo wszystko lektura niezwykle zajmująca. Tomasz Kizwalter bardzo dobrze czuje się w formie luźnej wypowiedzi, charakterystycznej bardziej dla eseju niż rozprawy naukowej. Dowodem na to niech będzie na poły biograficzny wstęp. Autor bogato cytuje teksty źródłowe, wypowiedzi uczestników wydarzeń. Jako student w Instytucie Historycznym UW miałem przyjemność uczęszczać na wykłady Tomasza Kizwaltera dotyczące ideologii w XIX wieku. $Z$ wielka satysfakcja odnotowywałem w tekście ślady jego licznych dygresji, łączących historię zdarzeniowa $z$ historią idei. Książka jest tylko namiastka tego doświadczenia, niemniej jednak mogę do niej $z$ czystym sumieniem zachęcić.

Jakub Szumski

Jakub Szumski - doktorant w Instytucie Historii PAN. 